Maxine David , Jackie Gower \& Hiski Haukkala (2011): Introduction: The European Union and Russia, Journal of Contemporary European Studies, 19:2, 183-188

http://www.tandfonline.com/toc/cjea20/19/2

\title{
Introduction: The European Union and Russia
}

\author{
Maxine David, University of Surrey, UK \\ Jackie Gower, ' King's College, London, UK \\ Hiski Haukkala, University of Tampere, Finland
}

The EU's multilevel system of governance means that the member states participate in the formulation and implementation of the Union's common policy towards Russia within the framework of the Brussels institutions while quite legitimately continuing to maintain bilateral relationships with Russia. In itself this is not unusual: the same is true in the case of the EU's foreign policies in general. However, the case of Russia is of particular importance and relevance for understanding the interplay between the formulation and conduct of foreign policy at the national and multinational (EU) levels and in particular for assessing the impact of the former on the coherence and effectiveness of the latter. There are a number of reasons for this.

Firstly, a significant number of member states have very extensive and intensive bilateral relationships with Russia, often officially designated as 'strategic' or 'special' partnerships and framed by bilateral treaties and agreements. Chief among them are four of the large member states, Germany, Italy, France and also more recently Spain. However, a number of smaller states such as Greece, Cyprus, Bulgaria, Finland and the Netherlands also have very close (although in the case of the latter, not always trouble-free) relations. Frequent bilateral summits take place and there is a dense network of meetings at political, official and civil society levels often resulting in important agreements, for example on energy, trade, security and culture.

Secondly, however, it is also the case that a significant number of member states have strained and even poor bilateral relationships with Russia. It is common in the literature to attribute this to the consequences of the 2004 and 2007 enlargements involving eight former members of the Soviet bloc (Raik, 2007; Light, 2008). Inevitably they brought considerable historical baggage to the EU - Russia table, including not only a legacy of suspicion towards their larger neighbour but also a number of outstanding bilateral disputes on borders, the treatment of Russian-speaking minorities and diverging narratives on key historical events such as WWII. However, new member states are by no means the only ones to have poor relations with Russia. In recent years some of the most serious bilateral disputes have involved 'older' member states, such as the UK, Denmark and Sweden. Although by no means always the case, bilateral disputes are sometimes uploaded onto the EU-level agenda which complicates and sours the EU - Russia relationship as a whole (Schmidt-Felzmann, 2008; Roth, 2009).

Thirdly, this very large variation in the character of bilateral relationships has not surprisingly resulted in a particularly sharp division of opinion between the member states as to the most appropriate and effective way of dealing with Russia; some argue for a pragmatic, instrumentalist strategy of constructive engagement while others prioritize the normative agenda or urge a policy of soft containment. Speaking in his capacity as Trade Commissioner, Peter Mandelson (2007) observed that: '[N]o other country reveals our differences as does Russia. This is a failure of Europe as a whole, not any Member State in particular. But it does our interests no good.' A Briefing Paper presented to the European Parliament's Committee on Foreign Affairs in 2009 indicated that the problem continues, observing that: '[E]ven before the war in Georgia in 2008, Russia had emerged as the 
single most divisive issue for the EU since the invasion of Iraq in 2003' (Wilson et al., 2009). Inevitably these deep divisions between the member states make it difficult to achieve the necessary consensus on policy towards Russia or often results in lowest common denominator outcomes.

Fourthly, there is also suspicion that some member states are playing a 'two-level game'taking a much more pragmatic stance at the bilateral level while concurring with the more normative-based multilateral agenda at Council meetings and working groups (Smith, 2006). It is not generally a matter of different objectives, but rather different priorities, depending on whether they are conducting policy at the bilateral or EU level (Gower, 2007). The obvious danger is that this 'two-level game' may send out signals to the Russians that they do not need to worry too much about what is said in the EU-institutional fora if Rome or Berlin or Madrid are still prepared to do business. As Katinka Barysch commented, member states are 'happy to leave the difficult bits of the EU - Russia relationship to the Commission and other EU institutions, while reassuring Putin that it is ultimately the capitals rather than Brussels that call the shots in foreign policy’ (Barysch, 2004, p. 54).

The final reason that the bilateral relationships of the EU member states are an important area of research in understanding the dynamics of EU - Russia policy is the continuing importance attached to them by Russia itself. Russia is very much a classic realist power that feels much more comfortable dealing with other 'Great Powers' like France, Italy, Germany and even the UK than the post-modern EU with its post-sovereignty agenda. It has felt the 'need to cultivate bilateral links with certain member states that cut across and undermine common EU policies' (Haukkala, 2010, pp. 146 - 147). Its recent Foreign Policy Concept specifically asserts that 'the development of mutually advantageous bilateral relationships with Germany, France, Italy, Spain, Finland, Greece, the Netherlands, Norway and some other West European States is an important resource for promoting Russia's national interests in European and world affairs' (Kremlin, 2008). One way in which it does so is by trying 'to exploit differences of opinion between the member states by using its special relations with individual EU leaders to advance its national interests inside the EU’ (Schuette, 2004, pp. 1-2).

Perhaps not surprisingly, the verdict of most scholars and practitioners therefore is that the impact of member states' bilateral relationships with Russia (irrespective of whether they are good or bad) has been overwhelmingly negative on the EU's attempt to formulate and conduct an effective common policy towards Russia, weakening its capacity to 'speak with one voice' and contributing to what is generally regarded as its underachievement, or even failure. However, this conclusion has been largely intuitive and based on a few wellpublicised incidents involving a few individual member states rather than a more comprehensive assessment of the impact of the bilateral relations of all twenty-seven states on the Union's common policy towards Russia.

This special issue is the product of a research project convened under the auspices of the EU - Russia Collaborative Research Network ${ }^{1}$ specifically to address these short-comings by bringing together an international team of academic experts in the foreign policies of all twenty-seven member states. An initial workshop was held at King's College London in April 2010 to discuss the overall themes and methodology. ${ }^{2}$ Papers on specific states, or groups of states, were then presented at the ECPR Fifth Pan-European Conference in Porto in June and the UACES Annual Conference at Bruges in September 2010. The seven articles included in the special issue have been selected to provide analysis of a representative sample of member states in terms of size, geo-strategic position, date of accession, energy dependency and historical links with Russia, as well as the different qualities of the relationships and general policy stances. By some of the articles focusing on geographically defined groups such as the Nordics, Benelux, Baltics, Iberian and Greece and Cyprus, it has been possible to cover a total of fifteen member states. However, as the authors show in their articles, while there are certainly enough similarities and 
commonalities among the members of the 'groups' to justify adopting this strategy, there are also important differences and contrasts which enrich the overall analysis and contribute to the development of a more nuanced understanding of the factors influencing and shaping a state’s bilateral relationship with Russia.

Although we did not want to be too prescriptive, the authors were asked to address three sets of core research questions to ensure a common framework for the analysis.

- What are the key factors that shape a particular member state's stance towards Russia; is it geopolitics, history, identity, leadership, security interests, trade, energy dependency? What makes a state adopt a friendly, pragmatic or critical stance towards Russia? Or are bilateral relations in reality more complex and nuanced, dependent on the particular policy area in question or which party is in power? Do bilateral relationships change over time or are there continuities?

- Which member states are able to exercise the most influence on the Union's Russia policy? On what is that influence based? Does it change over time?

- What impact do these bilateral relationships have on the Union's common policy towards Russia? Does the evidence support the widespread assumption that their effect has been negative or are there any cases where bilateral relationships or policy initiatives have provided synergies or reinforcement of the common EU objectives and strategies or where good relationships at a personal level have facilitated compromise and agreement? Is it possible to conceive of constructive bilateralism?

The first article is on Germany which is accurately described by its author Graham Timmins as 'undeniably the most significant' (p. 189) of the bilateral relationships with Russia, but which has also been one of the most widely criticised for sometimes prioritising national interests over those of the EU as a whole. What comes out most strongly is the depth of the economic relationship which underpins, and arguably also drives, the exceptionally close political relationship which he charts in detail from the end of the Cold War. He concludes that 'no EU member state has done more to promote EU policy on Russia than Germany but, by the same measure, no member state has arguably done more to undermine it' (p. 197), yet he asserts that Germany is unlikely to stray too far away from the multilateral EU track in the future.

The second article also focuses on one of the 'large' member states, the UK, but provides a stark contrast with the case of Germany both in terms of the quality of its relationship with Russia and its influence on the EU - Russia agenda. As Maxine David demonstrates, the UK's 'less than special relationship' with Russia during the same period has been strained and at times even poor, but its troubled bilateral relationship has not generally had a negative impact on the multilateral relationship. Unlike many other member states, the UK has not sought to upload its bilateral problems to Brussels and therefore the EU has been largely insulated from the potential damage of even 'crises' in UK - Russian relations. Interestingly, despite frequent political problems, the UK has managed to enjoy robust economic relations with Russia, indicating that it is not necessary to be subservient to Moscow politically in order to do successful business in the country.

Licínia Simão in her article considers a third large(ish) member state, Spain, which has recently developed a more substantial bilateral relationship with Russia and is becoming a more important actor with regard to the EU's Russia policy. She explores the rather surprising emergence of Spain as one of the states most sympathetic to Russia's position on a number of key international issues such as the status of Kosovo, the US missile shield, further eastern enlargement and the war in South Ossetia. She also considers its Iberian neighbour, Portugal, which as a small state on the EU's western periphery, has had only rather limited relations with Russia, although trade and tourism have developed in recent years. She concludes that 'smaller and relatively uninterested states such as Portugal could help the EU to build on constructive bilateralism to improve overall relations with Moscow’ (p. 219). 
The other four articles deal with the smaller EU member states but demonstrate that size is not the main determining factor when it comes to the nature of their relationships with Russia, with some like Greece and Cyprus being generally very close to Russia, others like the three Baltic states having estranged relations, and the Benelux and Nordic states falling on various mid-points on the spectrum. Greece and Cyprus enjoy what George Christou describes as 'excellent bilateral relations' (p. 230) with Russia but he challenges Leonard and Popescu's (2007) characterisation of them as 'Trojan horses' inside the EU. Instead, he argues that they are part of a broad coalition of member states led by France and Germany that take a pragmatic, interest-based, approach to the EU's policy towards Russia and their own impact on it, while generally constructive, has been modest. The same constraint stemming from the structural limitations of small states in the EU foreign policy-making process can be seen with respect to the three Benelux countries which Tom Casier argues lack the leadership and credibility to be seen as impartial brokers of a coalition for a coherent Russia strategy. Nevertheless, he shows that Belgium often manages 'to punch above its weight' (p. 242) as the host of so many international institutions, including of course the EU, and the Netherlands is an important economic trading partner with Russia, especially in the energy field. He also argues that the traditional integrationist impulse of these states has experienced something of a reversal and that they now approach relations with the EU in a more instrumentalist and pragmatic fashion, as reflected in their bilateral relationships with Russia. Economic interests drive these relations resulting in 'stepwise constructive engagement' in a wide range of policy fields.

The final two articles deal with those states that share the geopolitical space of the Baltic Sea region with Russia and therefore arguably are most directly affected by its policies and behaviour. They are all small states and share a certain basic asymmetry in their dealings with their much larger neighbour, but have tended to come to rather different conclusions about the best way of managing the relationship and of pursuing their objectives within the EU context. The authors also challenge the assumption that the 'Nordic' or 'Baltic' states necessarily draw the same policy conclusions or manifest similar behaviour patterns and explore the differences as well as the similarities among the members of their 'groups' in their dealings with Russia. Tobias Etzold and Hiski Haukkala contrast Finland's traditionally more circumspect and pragmatic relationship with Russia with Denmark and Sweden's greater propensity for overt criticism of Russia's political stance, leading to a number of quite serious bilateral disputes. The result has been that whereas Finland is generally believed to have played a constructive, and at times leadership role in developing the EU's strategy towards Russia, both Sweden and Denmark have been more passive and even on occasion uploaded their bilateral tensions to the EU level with negative results. More recently, the three Nordics seem to have been converging in their Russia policies, indicating that there is potential for a more shared and robust Nordic contribution in the future.

Finally, David Galbreath and Ainius Lašas analyse the 'Baltic factor', widely perceived in both Moscow and Brussels to have been one of the main reasons for the deterioration in EU - Russian relations since the 2004 enlargement. They explore the key issues which have dominated their distinctly 'rocky' (p. 263) bilateral relationship with Russia (minorities, borders, energy security and historical narrative) and the way in which they have been transposed onto the EU - Russian relationship. They also argue that as small and inexperienced new member states, they have found it difficult to influence the EU policy agenda and instead resort to playing their victim card and threatening to use their veto in the later stages of the policy-making process. Hence they are often perceived as agenda-spoilers rather than agenda-setters.

One of the most obvious conclusions from the articles is the wide variance in the factors influencing member states' relations with Russia with significant differences between them in terms of historical legacies, proximity, trade relations, energy dependency and security issues. It should really come as no surprise that it has been so difficult to reach 
agreement on specific policy positions in relation to Russia or indeed on the overall importance of the relationship for the EU. It is also clear that national policy stances towards Russia are indeed more complex and nuanced than is frequently suggested in the literature and the uni-dimensional division of states into friends/accommodators and critics/sceptics is too simplistic. It is important to look at specific policy areas and it is not uncommon to find a positive relationship in one policy area that is not mirrored in others. Furthermore, many of the articles trace the evolution of the bilateral relationships over a considerable period of time and while in some cases they show a remarkable degree of continuity, in others there is clearly a dynamic element with changes evident as a result of domestic elections or new circumstances presenting fresh challenges or opportunities.

The articles also suggest the need for a more nuanced understanding of the impact of bilateral relations on the Union's common foreign policy with regard to Russia. There is certainly evidence that they have made it more difficult for the EU to 'speak with one voice' and on occasions have undermined the coherence of the articulation and implementation of an effective common policy. The two areas where this is most evident are the normative agenda of promoting democracy and human rights to which some states have afforded a low priority and energy security where some states have been tempted to conclude favourable bilateral deals with Russian companies. Some bilateral disputes have also been uploaded onto the EU Russia agenda with largely negative consequences. However, there is also vidence that in some cases good bilateral relations have played a constructive role in setting the agenda, reinforcing the common policy by providing synergies, facilitating agreements with Russia or even preventing a complete breakdown of relations at times of crisis such as the second Chechen war 1999-2000 or the war in Georgia in 2008. So our conclusion is that while bilateral relations undoubtedly can undermine the Union's common foreign policy, they also have the potential to reinforce it and any overall assessment needs to recognise the possibility for constructive bilateralism, including in the case of Russia.

\section{Notes}

1 The network is supported by the University Association for Contemporary European Studies (UACES) and the British Association for Slavonic and East European Studies (BASEES). See http:// www.eu-russia.eu/.

2 The generous financial support provided by UACES and the journal European Security to enable this workshop to take place is gratefully acknowledged.

\section{References}

Barysch, K. (2004) The EU and Russia: Strategic Partners or Squabbling Neighbours? (London: Centre for European Reform).

Gower, J. (2007) The European Union’s policy on Russia: rhetoric or reality?, in: J. Gower \& G. Timmins (Eds) Russia and Europe in the Twentieth Century: An Uneasy Partnership, pp. 111-131 (London: Anthem Press).

Haukkala, H. (2010) The EU-Russia Strategic Partnership: The Limits of PostSovereignty Relations in International Relations (London: Routledge).

Kremlin (2008) The Foreign Policy Concept of the Russian Federation, 12 July. Available online at: http://archive. kremlin.ru/eng/text/docs/2008/07/204750.shtml (accessed 24 May 2011).

Leonard, M. \& Popescu, N. (2007) A Power Audit of EU-Russia Relations. Policy Paper (London: European Council on Foreign Relations).

Light, M. (2008) Keynote article: Russia and the EU: strategic partners or strategic rivals?, in: U. Sedelmeier \& A. R. Young (Eds) The JCMS Annual Review of the European Union in 2007, pp. 7-28 (Oxford: Wiley-Blackwell). 
Mandelson, P. (2007) The EU and Russia: Our Joint Political Challenge, 20 April. Speech, Bologna. Available online at:

http://trade.ec.europa.eu/doclib/docs/2007/april/tradoc_134524.pdf (accessed 24 May 2011).

Raik, K. (2007) A Europe divided by Russia? The new eastern member states and the EU's policy towards the East, in: J. Gower \& G. Timmins (Eds) Russia and Europe in the Twentieth Century: An Uneasy Partnership, pp. 205-225 (London: Anthem Press).

Roth, M. (2009) Bilateral Disputes between EU Member States, CEPS Working Document No. 319, August. Available online at: http://www.ceps.eu/files/book/1898.pdf (accessed 24 May 2011).

Schmidt-Felzmann, A. (2008) All for one? EU member states and the Union's common policy towards the Russian Federation, Journal of Contemporary European Studies, 16(2), pp. 169-187.

Schuette, R. (2004) EU-Russia Relations: Interests and Values - a European Perspective, Carnegie Papers, No. 54. Available online at: http://www.carnegieendowment.org/files/cp54.shuette.final.pdf (accessed 24 May 2011).

Smith, H. (Ed.) (2006) The Two-Level Game: Russia’s Relations with Great Britain, Finland and the European Union (Helsinki: Aleksanteri Institute).

Wilson, A., Popescu, N. \& Noël, P. (2009) The Future of EU - Russia Relations: A Way Forward in Solidarity and the Rule of Law. Briefing Paper, February (Brussels: European Parliament and DG External Policies of the Union). Available online at:

http://www.europarl.europa.eu/meetdocs/2004_2009/documents/dv/

pe407011en_wilsonpopes/pe407011en_wilsonpopescu.pdf (accessed 24 May 2011). 